\title{
Physical Condition and Self-Control Improves the Ability of Back Attack in Volleyball
}

\author{
Bujang \\ Physical Education \\ Universitas Islam 45 Bekasi \\ Bekasi, Indonesia \\ bujangunismabekasi@gmail.com
}

\author{
Aridhotul Haqiyah \\ Physical Education \\ Universitas Islam 45 Bekasi \\ Bekasi, Indonesia \\ aridhotulhaqiyah@yahoo.com
}

\begin{abstract}
This research aims to determine the effect of power, flexibility, and self-control towards the ability of back attack volleyball. The research method is a survey, and the analysis technique is path analysis. This research was held at the Islamic University of 45 Bekasi with a population of 30 athletes on student club (UKM) volleyball. The sampling technique used was total sampling. The instruments were a back and leg dynamometer for power leg muscle, hand dynamometer for power arm muscle, flexibility using sit, and reach test. Based on the result of the data analysis, the conclusions are: (1) power leg muscle directly affects the ability of back attack volleyball, (2) power arm muscle directly affects the ability of back attack volleyball, (3) flexibility directly affects the ability of back attack volleyball, and (4) self-control directly affects the ability of back attack volleyball.
\end{abstract}

Keywords: power, flexibility, self-control, back attack, volleyball

\section{INTRODUCTION}

Volleyball has become one of the most widely played participant sports in the world [1], also in Indonesia. One of the techniques that must be mastered in volleyball is smash. Smash is an attack technique by hitting the ball in the air and aiming to put the ball into opponents are without being able to block or returned by the opponent, then adding the score of the team. Smash is one of the techniques that must be mastered by a volleyball player because, in most of the game, smash is used for gaining the score and winning the match. Factors that support the success of player on hitting the ball that set up by the setter is precision or timing, which is precision when doing running, jumping, and hitting the ball in the air.

In a match, the audience will give an extraordinary appreciation if both teams showing the smash at high speed and sharp elevation angels. Then, in one condition, if the team that almost lose can get up again just because there is one of the members that doing the explosive smash. While in the other condition, the atmosphere in the team can be chaotic just because the opponent can do once or even twice the successful smash in their area. No doubt, the attraction of volleyball is about the performance player by showing the Smash. The good judgment of a player is often seen from their performance by doing smash, so there are a few people that appreciate the excellent performance of Libero, setupper, even service receiver, and another player. The high influence of the Spiker in volleyball, improve quality of smash becomes the primary orientation. So, sometimes, other techniques get less attention.

Smash is one of the arts in volleyball [2], a weapon for attacking in volleyball [3], a powerful blow where there is a contact from hand to the ball in full at the top, so the ball steep in high speed [4]. Smash is a spike that usually lethal because the ball is difficult to be returned [5] and how to play the ball efficiently and effectively in the rule of the game to achieve optimal results [6].

Volleyball has several types of smash that can be distinguished into two parts. First, based on the passes which are given by the setter are (1) Open Spike; (2) Semi Spike; (3) Quick Spike; and (4) Back Attack Spike. Second is the types of smash that distinguished by the strength and weakness when hitting the ball. They are (1) Hard Driven Spike, (2) Off Speed Spike (placing) and. In this study, the author will discuss "Back Attack Smash." Back attack Smash is an attack that is done by a Spiker, where the takeoff is done behind the attack line ( 3 meters line).

The back attack is a variation of the smash technique. The back-row players perform the attack. When one from three players in the back row jump and get contact with the ball from upper NET and jump from behind the line. Back Attack is invalid when the Libero became the set upper in the attack line (3 meters line), the Spiker jumped in front of the attack line and hit the ball which is passed by other setter or players.

North Bay Volleyball Official Association stated that Smash that can be called as Back Attack Smash if the backrow player jumped behind the attack line ( 3 meters line) and stroke the ball ideally through the net. Back Attack is a deadly attack. This attack can be the primary attacking strategy. Spiker that has higher jumping has power and good elasticity will be free to hit the ball even there are the blockers. The Spiker can point out the ball to the back row of the defender, sideways, or also get a bit of blocker to change the direction of the ball to the outside of the field. The ball is passed by 2 meters high from the net. Back Attack technique is the most sophisticated techniques in the volleyball. Because it is involving the muscle power from almost the whole body and needs a good elasticity and coordination from several parts of body, it is more complicated than other 
This high achievement can be achieved by deploying of techniques. Besides, the psychological aspect is also required for this technique.

The implementation of back attack is so complex, and there are so many factors that influence it, including the psychological aspect. However, in this study, the authors only discuss the influence of power legs and arms, flexibility and self-control. Based on the three factors above, the authors consider that it is the main factor in the Back-Attack Smash.

Power is often called as explosive power or muscular power. It is the muscle ability to spend maximum potential in a short time [7][8] and a speedy time [9]. From some previous opinions, we can conclude that power is the muscle's ability to point out the maximum potential in a concise time. According to their views, too, the strength of leg muscles to point out the maximum power in the shortest time. Likewise, with the arm, where the arms power is the muscles' ability to point out the maximum potential in a concise time.

Legs power is the strength used when people jump or lift the body by doing vigorously and quickly contraction to boost from the bottom to the top to make the high jump[10]. When the athlete performed the Back-Attack Smash, his legs power play vital role to lift his body to get the higher jump, in other to make an athlete can preparing well, he should have good legs power. Likewise, with the arms power, if an athlete has a good arms muscle power, he will be easier to swing his arm to do Back Attack Smash to the opponent's area. Both legs and arms power will be seen during the back attack. By having a good legs power, an athlete will be more comfortable to get air and choosing the direction to put the ball and arms power, let him hit the ball by powerful strength and directional.

Flexibility is related to the presence of more full joints and muscle elasticity joints ability to move [11] the body or its part as widely as possible without the occurrences of joint tension and muscle injury [12], to move as wide as possible [8]. Bompa proposed that "Flexibility refers to the range of motion around a joint. From all the above opinions, it can be concluded that Flexibility is the joints ability to move as wide as possible without the tension of joints and muscle injury [7].

Flexibility is needed during the back-attack smash, mainly to avoid the possibility of Injury, support the efficiency gestures, and fix the body composition. Also, the role of flexibility can be more comfortable to point out the ball to the area that we want and aim to avoid the block from the opponent and look for an empty space. Beside to direct the ball, it also can add the strength of back attack that caused by the swinging of both body and arm that are far from behind. From the above description, it can consider that someone who has an excellent flexibility and can-do back attack smash can produce a right combination of attack for the team.

These three physical aspects are not enough to perform a back-attack smash with optimal results if it is not combining by good self-control by an athlete. Restraint is a person's ability to manage emotions to stay under control and the ability to refrain from brutal action when there is a trigger or is in a strain condition. Self-control is the ability to guide one's own behavior, the ability to suppress or impede impulses or impulsive behavior [13]. all the abilities, both physical and psychic, and it means that the all elements of his soul are not influenced by lousy environment even can cause stress, to become a mature athlete, we must be able to accept criticism, not afraid to lose, and be always calm. Self-controlling is depending on how the individual can handle their emotion to stay focus. Their reaction to mistakes is one of the learning processes. Athletes must be able to control their own emotion whether on their selves, their friends, even on their opponents.

The above explanation can be concluded that an athlete who has leg power, right arm, and excellent flexibility even supported by good self-control, can do back attack smash well and gains a point for the team.

\section{METHOD}

This type of research is the research of quantitative associative. This research is determined to find out the causal relationship between 2 variables or more by using path analysis. The population of this research was 15 male and female volleyball athletes from volleyball UKM of UNISMA Bekasi, who had a position as Open Spiker and all-round. The instruments used in this research are (1) Vertical jump, this test aims to measure the power of athlete's legs by a centimeter unit [14], (2) Soft Ball Throw, this test measures the power of an athlete's arm by meters, (3) Sit and Reach, This test aims to measure the body's shape, by centimeters, (4) Psychological scale using Behaviorally Anchored Rating Scale (BARS) approach method to reveal self-control variable with Likert scale modeling, (5) Test of the ability on Back Attack Smash. This test aims to measure the ability of an athlete's back attack with a unit of frequency.

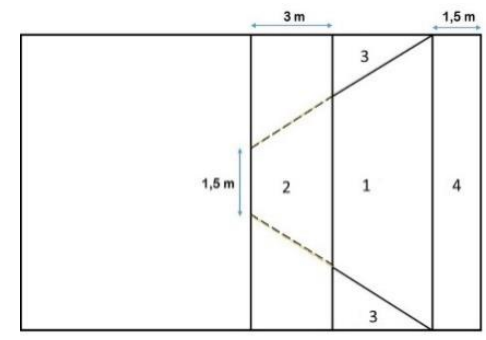

Fig. 1. The Test Diagram of Back Attack Ability

The data analysis technique used in this research is path analysis [15] by the help IBM SPSS [16] program for windows to know the influence of legs power, arms power, flexibility, and self-control on back attack ability on volleyball athletes from volleyball student units (UKM) of Islamic University 45 Bekasi.

\section{RESULTS AND DISCUSSION}

Based on the results of data analysis using path analysis, known effect of power leg, power arm, flexibility, and selfcontrol to back attack ability is summarized in Table 1 .

TABLE I. RESUlt SUMMARY OF STRUCTURAL TEST

\begin{tabular}{|l|l|l|l|l|l|}
\hline $\begin{array}{l}\text { Direct } \\
\text { Effect }\end{array}$ & $\begin{array}{c}\text { Path } \\
\text { Coefficient }\end{array}$ & t-cal & $\begin{array}{c}\text { p- } \\
\text { value }\end{array}$ & Conclusion & Remarks \\
\hline$\rho_{\mathrm{y} 1}$ & 0,443 & 5,504 & 0,000 & Sig & \multirow{2}{*}{$\varepsilon=$} \\
\hline$\rho_{\mathrm{y} 2}$ & 0,387 & 4,126 & 0,002 & Sig & \multirow{2}{*}{0,052} \\
\hline$\rho_{\mathrm{y} 3}$ & 0,230 & 2,266 & 0,047 & Sig & \\
\hline$\rho_{\mathrm{y} 4}$ & 0,383 & 4,487 & 0,001 & Sig & \\
\hline
\end{tabular}


Using the backward method, the path coefficients shown by the standardized coefficients (beta) column are obtained. From table coefficient, obtained value $\rho y 1=$ 0,$443 ; \mathrm{t}$-cal $=5,504, \mathrm{p}$-value $=0,000<0,05$ or $\mathrm{H}_{0}$ is rejected, which means the power arm muscle (X1) a positive direct effect on the ability of back attack volleyball (Y). Value of $\rho y 2=0,387$; $\mathrm{t}$-cal $=4,126$, p-value $=0,002<0,05$ or $\mathrm{H}_{0}$ is rejected, which means there is a positive direct influence between power arm muscle (X2) on the ability of back attack volleyball $(\mathrm{Y})$. The value of $\rho \mathrm{y} 3=0,230$; $\mathrm{t}$-cal $=$ 2,266 , p-value $=0,047<0,05$ or $\mathrm{H}_{0}$ is rejected, which means there is a direct influence of flexibility (X3) on the ability of back attack volleyball (Y). While the value of $\rho y 4$ $=0,383 ; \mathrm{t}$-cal $=4,487$, $\mathrm{p}$-value $=0,001<0,05$ or $\mathrm{H}_{0}$ is rejected, which means there is a direct influence of selfcontrol (X4) on the ability of back attack volleyball (Y).

The results of data analysis indicate that the physical condition very determines the achievements of athletes athletic. The physical condition aspect is the most essential part of all sports, primarily to support other aspects like technique, tactics and mental. Physical condition is crucial in helping the athlete's job in the match so it can perform optimally. Harsono explains that the athlete's physical condition plays a vital role in the training program[9]. The physical exercise program should be well planned and systematic and aimed at improving the physical fitness and functional abilities of the body system thereby enabling the athlete to achieve better performance.

Furthermore, the physical condition also plays a role to improve physical fitness for someone to achieve more productive work

Power analysis results in this study showed that in this case, the leg and arm power can enhance the ability of back attack. The results of this study support the theory that has been described on the previous page. The excellent power, especially the explosive power of leg muscles, determines a person to achieve optimal performance because the leg muscles are the main center of motion for the body as a whole. Several previous studies have suggested the same thing that leg and arm power contributes to the ability to smash the volleyball game[17]. Likewise, with research Helda Heldayana et al. explains that power leg and power arm can affect the ability of smash. However, the above studies have not been discussed about the back attack [18].

Power is needed in volleyball games, especially on smash execution. Particular volleyball game in doing smash, leg muscle power plays an important role. If you look at the behavioral motion during the smash, which begins with the prefix forwarded with a jump over the net, then to jump quickly and strongly required maximum leg power [19].

Likewise, the results of this study indicate that the ability to influence the ability of back attack volleyball game. The results of this study are supported by theories such as "Abstinence is the body's ability to perform exercises with a large or extensive amplitude of movement. The formation is one of the crucial elements of physical condition in studying movement skills, preventing injury, developing strength, speed, endurance, agility and coordination. The formation speaks of the ability of joint / wrist functions such as the joints of the shoulders, knees, legs, hips, wrists, and others. Ability of markedness is characterized by the extent of movement that can be performed on the joints/wrists.

The amplitude of movement well determines a person's ability to perform various forms of movement and skill. The higher the amplitude of the movement the more widespread the movement can do. The success of performing movements depends on the amplitude of the joint or the extent of movement that should exceed the required by movement [7]. A spike in a volleyball game will not be able to spike in this back attack spike powerfully and purposefully without being supported by the ability of the joints of the body, shoulders, legs, and arms. It is because of the necessary flexibility to optimize the use of muscle power of the arms, shoulders, abdominal muscles and muscles leg to jump.

Of the three components of the above physical conditions, arm power gives the most considerable influence, followed by power leg and subsequent flexibility. These results are in accordance with the function of each of these physical components. Legs' power of bodily parts that are needed in a back attack because the back attack needs a high jump to reach the ball. To get a high jump needed leg muscle power is prime. Meanwhile, power sleeves are required to hit the hard-hard ball that is directed to the opponent's field and may not be returned by the opponent. To get a hard punch is needed good arm muscle power. The functionality is enabled to direct the blow to avoid the opponent's block and lead on the opponent's empty field.

In addition to the three components of the physical condition above, this study also proves that self-control also gives a significant effect on the ability of back attack. Restraint is the ability of an athlete to control himself to act. Related to the back attack in the volleyball game is how so athlete controlled himself in a back attack, whether necessary or not. An athlete who can control himself will be able to read the situation in a match.

Thus, it can be concluded that the four variables partially provide a significant effect on the ability of a back attack by a spiker. To do a proper back attack, a spiker must have good leg and arm power. This is the character of the back attack itself is a smash that is done behind the attack line or line 3 meters from the net which requires a high jump to reach the ball as high as possible. Besides, the spiker is necessary to have good self-control to be able to contribute to smash back attack well and dare to take risks. Next, put the ball in certain areas on the opponent's field, making it difficult to predict by the opponent, a spiker must have excellent flexibility.

\section{CONCLUSION}

The results of data analysis and discussion that has been exposed above can be concluded that power limb, power arm, flexibility, and self-control significantly influence the ability of back attack in the volleyball game. Of the four factors analyzed in this study, arm power gives more considerable influence, followed by the energy, selfcontrol, leg, and the last is flexibility. Thus, it can be explained under a speaker to be able to perform a back attack by having a power leg, power arms and flexibility appropriate character from the smash back attack, the smash is done away from the net so that the three physical aspects above is required. Furthermore, a spiker must be able to 
[9] Harsono, Latihan Kondisi Fisik. Bandung: FPOK UPI, 2001.

control themselves in a back attack, so that the back attack that is radiated to the opponent field can be well directed.

\section{ACKNOWLEDGMENT}

This research was supported by our colleagues Universitas Islam 45 Bekasi and Post Graduate Program, the Universitas Negeri Jakarta, who provided insight and expertise that greatly assisted the research.

\section{REFERENCES}

[1] M. D. Tillman, C. J. Hass, D. Brunt, and G. R. Bennett, "Jumping and landing techniques in elite women's volleyball," J. Sport. Sci. Med., 2004.

[2] B. D, Belajar Bermain Bolavoli. Bandung: CV Pioner Jaya.

[3] F. B. J. Viera, Barbara R, Bola Voli Tingkat Pemula. Devisi Buku Sport. Jakarta: Raja Grafindo Persada, 2000.

[4] Mariyanto, Permainan Bola Besar II Bolavoli. Jakarta: Depdikbud, 2007.

[5] I. Kristianto, Pendidikan Jasmani. Surakarta: Yudistira, 2003.

[6] Muhajir, Pendidikan Jasmani. Bandung: Yudistira, 2007.

[7] O. Tudor, T. Bompa, C. Buzzichelli, and T. Edition, Periodization Training for Sports. .

[8] M. Sajoto, Peningkatan dan Pembinaan Kekuatan Kondisi Fisik. Semarang: Effhar dan Dahara Prize, 2002.
[10] I. H. A. Wahyudin, "Pengaruh Latihan Beban Antara Squat, Standing Calf Raise, dan Motivasi Berprestasi Terhadap Jumping Smash Bolavoli," vol. VIII, no. 2, pp. 223-238, 2017.

[11] D. Pekik, Dasar Kepelatihan Olahraga. Yogyakarta: FIK UNY, 2004.

[12] Ismaryati, Tes dan Pengukuran Olahraga. Surakarta: Universitas Sebelas Maret, 2011.

[13] J. P. Chaplin, Dictionary of Psychology. Kamus Lengkap Psikologi. Kartini Kartono. Jakarta: Raja Grafindo Persada, 2008.

[14] Widiastuti, "Tes dan pengukuran olahraga," Tes dan pengukuran olahraga, 2015.

[15] H. Muhamad, Memet; Aridhotul, Diktat statistik olahraga. FKIP: UNISMA Bekasi, 2015.

[16] Kadir, Statistika Terapan. Jakarta: PT. Rajagrafindo, 2015.

[17] M. R. Ifwandi, "Kontribusi Power Otot Tungkai Dan Power Otot Lengan Terhadap Pukulan Smash Pada Permainan Bolavoli Club Himadirga," J. Ilm. Mhs. Pendidik. Jasmani, Kesehat. Dan Rekreasi, vol. 2, no. 1, pp. 26-38, 2016.

[18] H. Heldayana, "Hubungan Antara Power otot lengan dan Otot Tungkai denga hasil spike semi pada cabang olahraga bolavoli," Junal Terap. Keolahragaan, vol. 01, no. 01, pp. 45-49, 2015.

[19] D. Susilawati, "Pengaruh latihan squat jump terhadap peningkatan tinggi loncatan smash dalam permainan bola voli pada siswa putra MTs Darussalam Japara Kuningan,” in Prosiding seminar nasional pendidikan jasmani. STKIP Seblelas April Sumedang, 2017. 